\title{
Art as an instrument to understand the concept of death
}

Whatsoever dieth and falleth, however and wheresoever it die and fall, it cannot fall out of the world, here it have its abode and change, here also shall it have its dissolution into its proper elements. The same are the world's elements, and the elements of which thou dost consists. And they when they are changed, they murmur not; why shouldest thou?

Marcus Aurelius (AD 121-80)

We continue with our series of articles regarding Art as an educational tool in medicine. ${ }^{1}$ This time, we will analyze the meaning of death, a highly helpful concept for every practicing physician. In this article, we will describe the concept of death in the light of two great poets, Jorge Manrique (1440-1479) and Rainer Rilke (1875-1926), based on two of their famous books: Coplas on the Death of His Father (Manrique), and Requiem (Rilke). ${ }^{2,3}$

In Coplas on the Death of His Father, Jorge Manrique wrote:

"Our lives are fated as the rivers

that gather downward to the sea

we know as death."

As expressed by Manrique, death is not actually an instance of departing but a point of return, since in the beginning there is only the inorganic plane (the sea), then comes a change in state with our birth into the organic plane (the river), where we live until the time of death, when we return to that inorganic state (the sea). Death enables the possibility of a new life because it obtains the necessary matter (atoms) and space from the old life to develop the new one. Life is like a big jigsaw puzzle, in which the life cycle can only go on as long as the course of death goes on as well, because the new is made from the readjustment of the old pieces resulting from the destruction of the old (Klimt). ${ }^{4,5}$

Moreover, considering that biology has taught us that unicellular organisms are literally immortal because they reproduce asexually and create new and identical organisms without leaving a corpse, organisms with specialized cells (sexual reproduction) diversify but become mortal; so it is understood that death not only allows for the renovation of life, but also its diversity and sophistication. ${ }^{6}$

In Rainer Rilke's Requiem, he stated:

"The great death which each one carries within that is the fruit around which all things turn..." "we live and exist from our own death, and death beats and grows within ourselves"...

"we are the laborers of our life plot destined to reaping our own death..."

As pointed out by Rilke, death does not emerge only when we die, but it is there, present from the time of birth. We are dying as long as we live because we are beings meant to die (Heidegger). ${ }^{6,7}$ According to the Stoic philosophers, life is like a lamp's light, which is the result of the consumption (death) of an oil from which it generates itself (Epictetus). For this reason, the dichotomy of life and death is a false one; both life and death are the front and back of the same phenomenon: the existence of entities (Bernard-Heidegger) ${ }^{6,8}$ Let us keep in mind that the only thing a man owns is his present; his past and his future are mental illusions, so no one loses any other life than the one he now lives (Marcus Aurelius). ${ }^{8}$

This is why defeating death does not mean opposing it (a useless resistance) but embracing and transcending it, giving life a meaning (redefinition), living life for the sake of love and dignifying actions (Frankl). ${ }^{9}$

In his Requiem, Rainer Rilke also stated:

"Death is the aggregation of existence."

With this phrase, Rilke underscores the concept that, were it not for death and its limiting and inexorable condition, a man's life would lack unity, would just become a pile of scattered and disconnected events, given that these events are ordered based on goals (achievements and enjoyments) that individuals propose hurried along by the deadline imposed by the certainty of their own death. As a result, this way death contributes to giving life its meaning (Simmel). ${ }^{10}$

To sum up, understanding the concept of death is critical for practicing physicians because it allows them to transcend the conceptual dichotomy of life and death and, therefore, acquire an inner strength to both care for severely ill patients and help them go through their agonizing experience, making art a valuable resource to achieve such understanding.

Carlos G. Musso, M.D. and Paula A. Enz, M.D. School of Medicine, Instituto Universitario del Hospital Italiano de Buenos Aires Argentina

http://dx.doi.org/10.5546/aap.2017.eng.4 


\section{REFERENCES}

1. Musso CG, Enz PA. El arte como instrumento educativo en medicina. Arch Argent Pediatr 2014;112(6):494-5.

2. Manrique J. Coplas a la muerte de su padre. Madrid: Cátedra; $1<986$

3. Rilke RM. Réquiem. Barcelona: Hiperion; 2008.

4. Musso CG. Obras maestras del arte universal: Muerte y vida de Gustav Klimt (1862-1918). Evid Act Pract Ambul 2009;12(2):60.

5. Morin E. El hombre y la muerte. Barcelona: Kairos;1974.
6. Favarger C, Gabus J, Erard M, Clerc F, et al. El hombre frente a la muerte. Buenos Aires: Troquel; 1964.

7. Moreno Claros LF. Martin Heidegger: el filósofo del ser. Madrid: Edaf; 2002.

8. Despeyroux D. La escuela de los filósofos: inspiraciones esenciales de los 100 pensadores más influyentes de la historia. Barcelona: Océano Ambar; 2008.

9. Frankl VE. El hombre en busca de sentido. Barcelona: Herder; 1991.

10. Simmel G. Schopenhauer y Nietzsche. Buenos Aires: Prometeo; 2005 